\title{
22. Şöyle Böyle mektupları ışı̆̆ında Muallim Naci ve Şeyh Vasfî
}

\section{Sefa TOPRAK1}

\begin{abstract}
APA: Toprak, S. (2021). Şöyle Böyle mektupları ışı̆̆ında Muallim Naci ve Şeyh Vasfî. RumeliDE Dil ve Edebiyat Araşturmaları Dergisi, (22), 381-394. DOI: 10.29000/rumelide.886075.
\end{abstract}

\section{$\ddot{O} \mathbf{z}$}

19. yüzyıl Türk edebiyatı tarihi aynı zamanda bir modernleşme dönemi tarihidir. Bu modernleşme hareketi kendisini dil ve edebiyat hareketi içerisinde de gösterir. Yenileşmenin öncü isimleri tarafından Batı normlarının geleneksel olanın karşısında adeta kurtuluş reçetesi olarak sunulduğu bu dönemde birçok alanda eski-yeni mukayeseleri ve çatışmaları yaşanır. Özellikle de şiir bağlamındaki eski-yeni tartışmaları dönemin edebiyatçılarını kutuplaşma derecesinde ayrıştırır. Batı edebiyatının "yeni”; Divan edebiyatı, Klasik şiir algısı ve bu şiiri oluşturan düşünce dünyası özelinde Doğu külliyatını oluşturan normların ise "eski” olarak tanımlandığı bu tartışmalarda sınırlar oldukça keskindir. Divan şiirinden bir kez olsun övgüyle bahsedilmesi "yeni” karşıtı olarak algılanmak için yeterlidir. Bu tartışmalar içerisinde isimleri “eski”nin savunucusu olarak anılan iki dost şair Muallim Naci ve Şeyh Vasfî Efendi de bulunur. İki şairin karşılıklı mektuplaşmalarından oluşan Şöyle Böyle adlı eser, dönemin edebi tartışmaları içerisinde yer alan Muallim Naci ve Şeyh Vasfínin edebiyata bakışlarını ortaya koyuyor olması bakımından oldukça önemli bir kaynaktır. Eser, iki şairin de geleneği çok iyi bilip içselleştirmelerinin yanı sıra gelişmeye-yeniliğe de oldukça açık olduklarını gösteren 12 mektuptan oluşur. Bu çalışmada Şöyle Böyle mektupları ışığında Muallim Naci ve Şeyh Vasfi'nin eski-yeni tartışmaları içerisinde edebiyata ve şiire bakış açıları incelenmiştir. Yapılan inceleme sonucunda iki şairin de içinde yetiştikleri gelenekten bağların koparmamakla birlikte yeniliğe ve modernliğe de kapalı olmadıkları, edebi esere Doğu-Batı bağlamından uzak bir güzellik algısı ile baktıkları görülmüştür.

Anahtar kelimeler: Şöyle Böyle, Şeyh Vasfî, Muallim Naci, mektup, tenkit

\section{In the light of Şöyle Böyle letters, Muallim Naci and Şeyh Vasfî}

\begin{abstract}
The history of 19th century Turkish literature is also a history of modernization. This modernization movement also shows itself in the language and literature movement. In this period when Western norms are presented as a prescription for salvation against the traditional by the pioneers of innovation, old-new comparisons and conflicts are experienced in many areas. Especially in the context of poetry, the old-new debates differentiate the literati of the period to the degree of polarization. In these literary debates, Divan literature, Classical poetry perception and the world of thought forming this poem are targeted. The "new" of Western literature in the French literature; The boundaries are very sharp in these debates, where the norms that constitute the Eastern corpus in the Divan literature are defined as "old". The praise of Divan poetry just once is enough to be perceived as the opposite of "new". In these discussions, there are also two friendly poets Muallim Naci and Şeyh Vasfî Efendi, whose names are known as the advocates of the "ancient". The work
\end{abstract}

Öğr. Gör., Zonguldak Bülent Ecevit Üniversitesi, Türkçe Öğretimi Uygulama ve Araştırma Merkezi (Zonguldak, Türkiye), sefatoprak.67@gmail.com, ORCID ID: oooo-ooo2-7183-936X [Araştırma makalesi, Makale kayıt tarihi: 23.12.2020-kabul tarihi: 20.03.2021; DOI: 10.2900o/rumelide.886075.]

Adres $\mid$ Address

RumeliDE Dil ve Edebiyat Araşttrmaları Dergisi $\quad$ RumeliDE Journal of Language and Literature Studies Osmanağa Mahallesi, Mürver Çiçeği Sokak, No:14/8 Osmanağa Mahallesi, Mürver Çiçeği Sokak, No:14/8

Kadıköy - İSTANBUL / TÜRKIYE 34714 Kadıköy - ISTANBUL / TURKEY 34714 e-posta: editor@rumelide.com

e-mail: editor@rumelide.com

tel: +90 505 7958124, +90 2167730616 phone: +90 505 7958124, +90 2167730616 
named Şöyle Böyle, which consists of the mutual correspondence of two poets, is very important in terms of revealing their perspective on literature within the literary discussions of the period. The work consists of 12 letters showing that both poets know the tradition very well and internalize it, as well as being very open to development and innovation. In this study, in the light of such letters, Muallim Naci and Şeyh Vasfi's perspectives on literature and poetry in the old-new discussions were examined. As a result of the investigations, it was concluded that both poets did not break their ties with the tradition in which they grew up, but they were not caught up in innovation and modernity, and they viewed the work with a perception of beauty away from the East-West context.

Keywords: Şöyle Böyle, Şeyh Vasfí, Muallim Naci, letter, criticism

\section{Giriş}

19. yüzyll, Türk modernleşmesinin hemen her alanda ivme kazandığı bir dönemdir. Askeri ve idari yönetim sistemlerinde Batılı-modern pratiklerin uygulanmaya başlaması yenilik hareketinin diğer sahalara da yansımasına yol açar. Toplum yaşamına henüz yansımamış olsa bile Batılı yaşam normları dönemin aydınları tarafından kurtuluşun vazgeçilmez birer reçetesi olarak görülmeye başlar. Matbaanın yerleşmesi, basın hayatının hareketlenmesi ile birlikte dönemin edebiyatçları yeniliğin öncülüğünü yaparlar. Dünyayı duyuş ve algılayış biçimlerindeki Batıya dönük değişim hareketi, dil ve edebiyatın yönünü de aynı eksene çevirir. Nesirde henüz yıkılması gereken bir gelenek yahut asırlardır süre gelen bağlayıcı bir kalıp olmadığı için; gazetelerde, dergilerde yazılan nesir türü eserlerde veya nesir dilinde yazarlar daha rahat hareket ederler. Fakat iş Fransa özelinde Batılı şiir anlayışı ve özelliklerini Türk şiirine uygulamaya geldiğinde yenilikçi şairlerin karşılarında yüzyllar boyunca süregelen bir Klasik şiir anlayışı ve şekilleri bulunur.

Bu bakımdan dönemin yenilikçi yaklaşımlarının şiir karşısında kendi rüştlerini ispat edebilmeleri hiç de kolay olmaz. "Yeniliğin" yerleşebilmesi, kabul görebilmesi için halen yaşamını sürdüren geleneksel olandan bağların tamamen koparılması gerekir. Bunun için de Divan şiirine ve geleneğe dair ne varsa alenen yıkımı için çalışılır. Zira yeni edebi normların kabulünün ancak bu şekilde yerleşebileceğine inanılır. Artık Doğuya ait ne varsa eski ve insanlığı karanlığa götüren; Batıya ait ne varsa iyi ve aydınlığın habercisi olarak telakki edilir.

Burada şair ve yazarları bekleyen birçok zorluk vardır. Birincisi henüz dillerine dahi tam hâkimiyet kuramadıkları bir dünyanın içine girmeye çalışıyor olmak onlar için hiç de kolay olmaz. Topluma “aydınlanmanın” kapısı olarak gösterilen Batıya ait ürünlerin çeviriler yoluyla Türk halkına öğretilmesi gerekmektedir. Batılı insanın zihin dünyasını, Türk insanına öğretmek için felsefi metinlerin çeviri yoluyla verilmesi gerekir fakat bu işin gerçekleşmesi için öncesinde büyük bir okumaya, titiz-seçkinci bir çeviriye ve fayda-zarar gözetiminde bir aktarıma ihtiyaç vardır.

Dönem aydınlarımızın tercihi bu uzun ve zahmetli süreçten ziyade Batının edebi ürünlerine yönelmek olur. Nitekim Batılı roman ve şiirlerin ilk çevirilerinden itibaren artık yüzyllardır süregelen şiir ve anlatı gelenekleri ile ilişkiler kesilmeye başlanır ve geleneksel edebi türlere karşı büyük bir itibarsızlaştırma çalışmaları yürütülür: toplumdan kopuk olmak, belli bir zümreye ait olmak, ahlaka mugayir olmak ve anlaşlamamak gibi. Yeni şiirin gür sesinde ise toplum, toplumsal fayda, ahlaki öğretiler, esastır. Söylem ve üslup da kendini buna göre ayarlamaktadır. Her ne kadar Klasik şiirin şekilleri devam ediyor olsa da işlenen temler ile birlikte artık kasidenin kaside, gazelin ise gazel olmadığı aşikârdır.

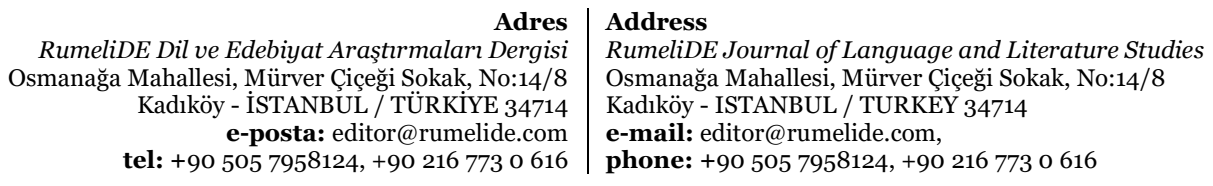


Yenilikçiler tarafından, kalben bağlı oldukları zevkin ve hissin; aklın ve sosyal faydanın gereğiyle yıkılması tek çare olarak görülür. Şiirler üzerinden ahlaki öğretilerin toplumu düzene sokacağı, yeniden millet olmanın büyük başarısının yakalanacağı düşünülür fakat “yeni” olanın kabul görmesi ve yerleşmesi hiç de kolay olmaz. Zira gerek şiiri okuyanlar gerekse yazanlar için, içinde büyüdükleri geleneğin duyuş ve zevkine olan aşinalık devam etmektedir. Bu bakımdan Divan edebiyatına, Klasik şiir algısına ve onun üzerine oturduğu temel esaslara topyekûn savaş açllması, geleneksel olanı sürdürmek isteyenleri rahatsız eder.

İşte bu noktada edebiyat tarihimiz içerisinde sıkça karşımıza çıkacak, isimleri değişse bile temelde tartışma mevzuları aynı olan "eski-yeni” tartışmaları baş gösterir. Özellikle de şiir bağlamındaki eskiyeni tartışmaları dönemin edebiyatçılarını kutuplaşma derecesinde ayrıştırır. Batı edebiyatının "yeni”; Divan edebiyatı, Klasik şiir algısı ve bu şiiri oluşturan düşünce dünyası özelinde Doğu külliyatını oluşturan normların ise "eski" olarak tanımlandığı bu tartışmalarda sınırlar oldukça keskindir. Divan şiirinden bir kez olsun övgüyle bahsedilmesi “yeni” karşıtı olarak algılanmak için yeterlidir.

Bu tartışmalar içerisinde isimleri "eski”nin savunucusu olarak anılan iki dost şair Muallim Naci ve Şeyh Vasfî Efendi de vardır. Edebiyat tarihi kitaplarında iki isim de eskinin muhafazakârlığını yapmış olmak ithamıyla karşımıza çıkar. İki şairin karşılıklı mektuplaşmalarından oluşan Şöyle Böyle adlı bir eseri vardır. $\mathrm{Bu}$ eser dönemin edebi tartışmaları içerisinde onların edebiyata bakışlarını ortaya koyuyor olması bakımından oldukça önemlidir. (Gökçe, 2014: 251) Eser, iki şairin de geleneği çok iyi bilip içselleştirmelerinin yanında gelişmeye-yeniliğe de oldukça açı olduklarını gösteren 12 mektuptan oluşur.

Dönemlerinde eski zihniyetin devamcıları olarak algılanmaları oldukça ilginçtir. Bu kanıdaki en büyük etken ikisinin de geleneksel olanı terk etmeden modern olana ilgi duyuyor olmalarıdır. Zira ikisi de edebiyatta Doğu-Batı ayrımından ziyade "güzel" olanın peşinde olduklarını söylerler ve sözün de "hale, zamana, mevkie göre" değişebileceğini belirtirler. Onlar edebiyatta eski veya yeni ayrımını değil sadece "güzel" ve "çirkin" ayrımını kullanırlar: "Bizce dünyada ne kadar güzel söz var ise cümlesi edebiyattan ma'dûddur, ne kadar çirkin söz var ise cümlesi edebiyattan matrûddur.” (s.5) Bu rikkatli edebiyat anlayışı ister Doğuya ister Batıya ait olsun bir eserin çok iyi seçimini gerektirir.

Naci'ye göre Batı edebiyatı taklit edilebilir fakat bu işe güzel ve çirkini ayırt edebilecek "milli” bir dikkatle bakılması gerekir. (Tarakçı, 1994: 26) "Sözde mana, manada hakikat, letafet" arayan Naci, bu konuyu özellikle dile getirerek mektubunda şöyle söyler: "Dışarıdan alacağımız şeylerin ne gibi şeyler olması gerektiğini neden bilmeyelim?” (s.22) Bu konuda aynı hassasiyeti sahiplenilen gelenek içerisinde de uygulamak niyetinde olan Naci, "münasebetsiz" olarak tanımladığı sözleri de "milli edebiyatımız" diye takdir edip durmayacağını belirtir. Burada ve daha birçok yerde Naci'nin zikrettiği millilik bahsi gelenek ve din bağlamı çerçevesindedir. (Özgül, 2016: 67) ve bunun gibi birçok fikir mektupların içerisinde yer almaktadır.

Bu çalışmada, Muallim Naci ve Şeyh Vasfî bağlamında edebiyat tarihimizdeki edebi tartışmalar üzerine yapılacak herhangi bir çalışmaya fayda sağlaması açısından Şöyle Böyle'deki mektupların eskiyeni mukayeseleri bakımından iki şairin edebi görüşleri üzerinden okunması gayreti içerisine girildi. Zira dönemin tartışmaları içerisinde bizzat bulunmuş iki önemli ismin kaleminden çıkan Şöyle Böyle mektupları, yayımlandıkları dönemde okuyucular tarafından dikkatle takip edilmiş, üzerine birçok edebi mahfilde konuşmalar cereyan etmiş olmasına rağmen günümüz araştırmacılarının gözünden

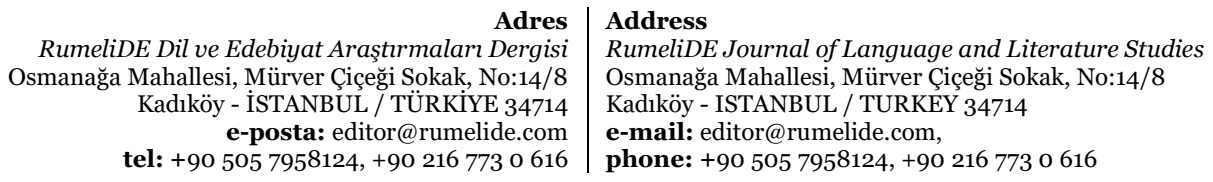


kaçmış bulunmaktadır. Özellikle de Muallim Naci gibi yeniliğe açık olmakla birlikte gelenekten beslenmeyi göz ardı etmek istemeyen bir ismin edebi mektupları onun üzerine yapılacak olan çalışmalara büyük katlı sağlayacaktır. Nitekim Şeyh Vasfî için de şüphesiz aynı durum söz konusudur ki kendisi de yakın dostu olan Naci'nin edebi fikirlerine ortaklık etmektedir. Elimizdeki mektuplar bunun en canlı şahididir.

Çalışmada, şairlerin hayatları genel hatlarıyla verildikten sonra eserin özellikleri üzerinde duruldu ve sırasıyla mektuplaşmaların muhtevası verildi. Bunu yaparken konu bağlamında üzerinde durulması gereken, yoruma ihtiyaç duyan noktaların biraz daha açlması gayreti içerisine girildi ve sonuç olarak da mektuplar özelinde şairlerin edebiyat algıları üzerinde değerlendirmelerde bulunuldu.

\section{Muallim Naci ve Şeyh Vasfî}

Muallim Naci ve Şeyh Vasfî Efendi, 19. asır Türk edebiyatı tarihinin isimleri sıklıkla birlikte anılan iki dost şairidir. Aralarındaki samimiyet birbirlerinin şiirlerine nazireler yazacak kadar ileri seviyededir. Şeyh Vasfî Efendi (1851-1910), İstanbul doğumludur ve asıl adı Ali’dir. İlköğrenimini Nakşibendi şeyhlerinden olan babasından alır. Babasının vefatı ile Kefevî dergâhının postnişinliğine getirilir. Dergâhtaki dini-tasavvufi derslerinin yanı sıra dönemin birçok mektebinde kitabet ve inşa dersleri verir; yazdığı sarf ve nahiv kitapları medreselerde okutulur. Farsçaya olan hâkimiyeti oldukça güçlüdür, Doğu edebiyatının güçlü isimlerinden çeşitli çeviriler yapar. Şiir, yazı ve mektupları Tercümân-ı Hakîkat, Saâdet ve Mürüvvet gibi dönemin birçok gazetesinde yayımlanır. Muallim Naci'ye karşı duyduğu hayranlık ve dostluk bütün edebî çevrelerce bilinmektedir. Öyle ki Naci'ye olan vefasını vefatından sonra onun gazete ve dergilerdeki şiirlerini Yâdigâr-ı Nâcî adlı bir eserde toplayarak gösterir. Şairliği ile Tevfik Fikret, Cenab Şahabeddin, Neyzen Tevfik gibi isimleri etkilemiş olsa da döneminde çok fazla ön planda tutulmamıştır. (Özsarı, 2010: 71-72; Tanpınar, 2011: 267) Adı, Mehmet Kaplan tarafından Ara Nesil olarak adlandırılan edebiyat grubunda, Klasik edebiyatı sürdürmek isteyenler içerisinde anılsa bile, edebiyatta yeniliğe açık olduğuna dair bilgi veren kaynaklar da bulunmaktadır. (Boşça, 2010: 5) Şeyh Vasfî’nin edebi kişiliği, ne yazık ki bugüne kadar sadece Muallim Naci ile yakın arkadaşlığı ve dostluğu üzerinden anılmaktadır. (Gökçe, 2014: 28) Muallim Naci ile olan yakınlıkları sadece dostlukla kalmaz, edebiyat algılarında da ortak bir düşünceleri bulunur. Bu ortak düşünceler karşılıklı yazdıkları ve Tercümân-ı Hakîkat’te yayımladıkları mektuplarında dile getirilir. Daha sonra kitap haline getirilen bu mektuplar Şöyle Böyle adı ile yayımlanır.

Muallim Naci (1849-1893): Asıl adı Ömer'dir, İstanbul doğumludur. Yedi yaşında babasının vefatından dolayı Varna’ya gider ve ilk eğitimini orada alır. Küçük yaşta Arapça ve Farsça öğrenen Ömer, Nâci mahlasını, Giritli Aziz Ali Efendi'nin Muhayyelat'ından alır. Gençliğinde Anadolu ile birlikte Osmanlı coğrafyasının birçok bölümünü çeşitli vazifeler ile dolaşır. İstanbul'a döndüğünde Tercümân-ı Hakîkat'te görev almasıyla birlikte telif ve tercüme yazı ve şiirleriyle tanınmaya başlar. Tanzimat döneminin yenilikçi anlayışının hüküm sürdüğü sırada Naci’nin Ahmet Mithat Efendi'nin başında olduğu Tercümân-ı Hakîkat’te eski şiir tarzı ile şiirler yazmaya başlaması bu tarz zevk sahibi olanları umutlandırır ve edebiyatta eskiyi savunanlar Muallim Naci'nin çevresinde toplanmaya başlar. Bu gruplaşma yeni edebiyatın savunucuları tarafından tepkiye neden olur ve edebiyat tarihimizde

Bu noktada Dr. Arif Yılmaz’ın çalışmasını zikretmemiz yerinde olur. Zira kendisinin Şöyle Böyle üzerine müstakil bir çalışması mevcuttur. Yılmaz’n, Şeyh Vasfínin hayatı ve edebi kişiliği üzerinde odaklanan çalışmasının ikinci bölümünde mektupların yeni harflere aktarımı verilmiştir. Bakınız: Arif Yılmaz, "Şeyh Vasfi ve Muallim Naci ile Mektupları: Şöyle Böyle”, Türkçe Mevsimi Yayınları, Uşak, 2012.

RumeliDE Dil ve Edebiyat Araşttrmaları Dergisi Osmanağa Mahallesi, Mürver Çiçeği Sokak, No:14/8 Kadıköy - ISTANBUL / TÜRKIYE 34714 e-posta: editor@rumelide.com tel: +90 $5057958124,+902167730616$
Address

RumeliDE Journal of Language and Literature Studies

Osmanağa Mahallesi, Mürver Çiçeği Sokak, No:14/8

Kadıköy - ISTANBUL / TURKEY 34714

e-mail: editor@rumelide.com,

phone: +90 505 7958124, +90 2167730616 
"Demdeme", "Zemzeme" gibi edebi münakaşaları ortaya çıkarır. (Uçman, 2005: 315-317 ; Gariper, 2013: 117; Enginün, 2012: 519-528; [Tansel], 1951-1953: 159-200)

Edebiyat tarihi kitaplarımızın birçoğunda yaşadıkları dönemde eski-yeni kutuplaşması içerisinde o dönemin tartışmalarının getirmiş olduğu gruplaşmalardan dolayı Muallim Naci ve Şeyh Vasfî ismi eskinin temsilcisi, taraftarı olarak gösterilir. Bu noktada eski taraftarlığının öncüsü olarak gösterilen Naci, aslında o dönemde birçok edebiyatçının yaptığını yapar. Ya da dönemin birçok şairi -ki buna yeniliğin öncülerinden Namı Kemal de dâhildir- Muallim Naci gibi içinde büyüyüp yetiştikleri edebiyatın zevkini ve âdetini sürdürerek gazeller ve kasideler yazar. Naci'nin eskinin taraftarıymış gibi görülmesi ise kendi yazdıklarından ziyade etrafında eski şiir anlayışını sürdürmek isteyenlerin toplanıyor olmasından ileri gelir.

Daha sonrasında ise Recaizâde Mahmud Ekrem ile girişmiş olduğu birçok edebi tenkit, onu eskinin savunucu köşesine yerleştirir ve kendisi de bunu destekleyecek şiirler kaleme alır. Nitekim 19. yüzyıl Türk edebiyatı tarihinin ana kaynaklarından olan Ahmet Hamdi Tanpınar'ın da belirttiği gibi eğer "Nâci iyi okunursa, onun mutlak eski taraftarliğının bir masal olduğu görülür. Hakikatte o, iyi ve güzel mânâlarında şark ile garbın arasında bir fark olabileceğine inanmiyor ve milliyetperverliği bir nevi gelenek fikriyle tefsir ediyordu." (Tanpınar, 2009: 534)

Fakat İnci Enginün, bu konuda Şeyh Vasfînin, Naci ile yakın arkadaşlığından dolayı, onun üzerindeki etkisinde bahseder ve Naci'nin eski edebiyat safında yer almasındaki önemli etkenlerden birinin de Şeyh Vasfî olduğunu söyler: "Naci”nin eski edebiyat taraftarl sayılmasının en önemli sebebi sorumluluğuna birakılan Tercümân-ı Hakikat’i eski edebiyatı sürdürenlere bırakmış olmasıdır. Bunlardan biri de Kefevi dergâhn postnişini olan ve Cenab başta olmak üzere birçok genci teşvik eden ve etkileyen Şeyh Vasfi'dir." (Enginün, 2012: 527)

Naci’nin eskiye bağlllığı dile getirildikten sonra yeniliğe de açı olduğuna dair tespitlerin olduğu eserler olmakla birlikte Şeyh Vasfî için bu türden yaklaşım neredeyse hiç yoktur. Yaşadığı dönemde çok ön planda olmasa da birçok şairi etkilemiş, birçok konuda telif ve çeviri eserler vermiş Vasfî Efendi'nin isminin sadece gelenekçi-muhafazakâr kısımda anılıyor olması, bu durumun kesinliğini irdelemek adına kendisinin bütün eserleri üzerinden tekrar değerlendirilmesini gerektirir. Şöyle Böyle mektupları da bu incelemenin başında gelir. İnci Enginün, Şöyle Böyle ve yazarları için kesin bir dille: "Bu kitabın ilginç yanı, Naci”nin eski edebiyatın savunucusu biriyle yazışmasıdır. Dağınık fikirleri, slk slk kendi tecrübeleriyle dile getiren Naci, eskiyi iyi biliyor, yeniyi bilir görünüyor, fakat tercihi kesinlikle eskidir.” (Enginün, 2012: 526) hükmünü verse de eserin içeriğinde Şeyh Vasfi’nin de Naci gibi edebiyatın gelişmesine katkı sağlayacak yenilikçi yaklaşımlara açık olduğu görülmektedir.

İşte bu noktada çalışmamızda ele alacağımız mektupların incelenmesi bu tartışma içerisinde iki şairin yerinin tespitinde olumlu bir katkı sağlayacağı şüphesizdir. Naci ve Şeyh Vasfî Efendi'nin yeniliğe kapalı olduğu algısının gerçek olup olmadığını bir kez daha kendi eserleriyle ortaya koymak adına elimizdeki Şöyle Böyle adlı eser önemli bir amaca hizmet etmektedir. Zira eserde iki şairin de yeni karşıtı; gelenekçi-muhafazakâr olduğu eleştirisine yeni yaklaşımlar getirebilecek birçok ifade ve tespitler vardır. Mektuplara konu olan meseleler, dönemin edebi tartışmaları içerisinde cereyan eder ve bizzat bu olayların muhatapları tarafından kaleme alınır. Bu bakımdan eser iki şairin de edebiyat düşüncelerini daha iyi görmek adına oldukça önemli bir kaynaktır.

\title{
3. Şöyle Böyle
}

\author{
Adres | Address \\ RumeliDE Dil ve Edebiyat Araştırmaları Dergisi $\quad$ RumeliDE Journal of Language and Literature Studies \\ Osmanağa Mahallesi, Mürver Çiçeği Sokak, No:14/8 Osmanağa Mahallesi, Mürver Çiçeği Sokak, No:14/8 \\ Kadıköy - İSTANBUL / TÜRKIYE 34714 Kadıköy - ISTANBUL / TURKEY 34714 \\ e-posta: editor@rumelide.com e-mail: editor@rumelide.com, \\ tel: +90 505 7958124, +90 2167730616 phone: +90 505 7958124, +90 2167730616
}


Şöyle Böyle 3 gerek edebi mektup türünün güzel bir örneği olması bakımından gerekse edebiyat tarihimiz açısından yaşadıkları dönemde çeşitli edebi tartışmalara konu olmuş iki şairin edebiyat ve şiir hakkındaki görüşleri için önemli bir kaynaklık ediyor olmasına rağmen pek de göz önünde bulundurulmayan ve üzerinde çokça durulmayan bir eserdir. Çeşitli açıdan eserleri incelenen hayatı birçok araştırmacı tarafından araştırılan Muallim Naci'nin şöhreti bile bu kitabı hatıra getirme noktasında yeterli olmamışsa bunun sebebi biraz da eserin diğer yazarı olan Şeyh Vasfî Efendi’ye bakış açısı ile alakalı olabilir. Edebiyat kaynaklarımızın, yaşadığı dönemde pek de ön planda bir isim olmadığını tekraren zikretmesi onun vermiş olduğu eserlere biraz da olsa gölge düşürmektedir. Şöyle Böyle de bundan nasibini almış olsa gerektir.

İki dost şairin kaleminden çlkan ve mektup türünün güzel bir örneğini teşkil eden Şöyle Böyle adlı eser, Şeyh Vasfî ve Muallim Naci'nin daha önce Tercümân-ı Hakîkat’te 5 Şubat - 9 Haziran 1885 tarihleri (Çetin, 2018: 662) arasında aralıklarla yayımlanan karşllıklı altışar mektubundan oluşmaktadır. 109 sayfa olan eser, hicri 1302 tarihlidir ve Kitapçı Arakel tarafından İstanbul'da basılmıştır. Mektuplaşmalarda Muallim Naci, Mes'ûd-ı Harâbâtî mahlasını kullanmaktadır. Toplam 12 mektubun bulunduğu eserin başında yazarların ortak imzasını taşıyan bir de "Mukaddime" bölümü bulunmaktadır. Bu bölümde Şeyh Vasfî ve Muallim Naci mektupları yazma gayretinde bulunmalarının sebebini belirtmekle birlikte mektupları neden yayınladıklarının cevabını da verir.

Amaç, Osmanlı edebiyatının yeni yetişen kalemlerine katkıda bulunmak, onlara yeni fikirler vermek; bir nevi yol göstericiliğinde bulunmak ve asıl fikirlerin tartışma yoluyla ortaya çıtığını vurgulamaktır. Zira onlara göre ilerlemenin yegâne çıkış noktası fikirdir ve fikirde itidali yakalamak da ancak fikir alışverişinden geçmektedir. Bu eser de "her şeyde medâr-ı terakki olan telâhuk-ı efkâr esasına istinaden vücuda getirilmiştir." (s.4) Şeyh Vasfî ve Muallim Naci, mektupların gençlerin dikkatini çekmeyi de başaracağından oldukça emindir zira onlara göre eser, edebiyat âleminde yeni yetişen gençlerin dikkatini çekebilecek şekilde Osmanlı edebiyatının ilerlemesine hizmet edecek bir takım kapsayıcı düşünceler ve tespitlerden başka geçmişteki edebiyatçlların seçme eserleriyle de süslenmiştir.

Ortak gayelerinin yeni yetişecek kalemlere edebiyat ve şiir hakkındaki fikirleri beyan etmek olduğunu dile getiren Şeyh Vasfi ve Muallim Naci, edebiyatın gelişiminde asıl dikkat edilmesi gereken noktanın: zamanın/fikirlerin değişimine göre sözün de değişebileceğini kabul etmek olduğunu belirtir. "Bir zamanlar edebiyat-ı Osmâniye âleminde Nefî̀ninki gibi eserler birinci derecede addolunurken şimdilerde ise o tarzda şiir yazanlar beğenilme dikkatini çekemediklerinden yanında bir de ayıplanmaktadırlar. Onun güzelliği o zamana göreymiş. Zamanımızda başka bir güzellik aranmakta." (s.7) Burada çağın artık yeni bir tarz gerektirdiğini, dünyayı algılayış biçimi ile birlikte insanların güzellik anlayışlarının da değiştiğinin ve bu değişimin beraberinde yeni bir güzellik algısı doğurduğunun altı çizilmekte ve "eski tarzın taraftarlarının bu cihetle yanılmakta" oldukları belirtilmektedir. "Şimdi şïrinde sevgilinin bulunduğu yerde dolaşır bir dilenci olduğunu söyleyen şaire kimse aferin demez." (s.7)

Onlara göre eski-yeni; Doğu-Batı gibi ayrımlardan ziyade sözün mana ve söyleyiş bakımından güzelliği esastır: "Bizce dünyada ne kadar güzel söz var ise cümlesi edebiyattan ma'dûddur, ne kadar çirkin söz var ise cümlesi edebiyattan matrûddur." (s.5) Bu bağlamda edebiyatta "güzelliğin" esas olduğunu

3 Şöyle Böyle, Mes'ûd-ı Harâbâtî, Şeyh Vasfî, İstanbul, 1302, Matbaa-i A.K. Tozluyan. (Alıntılar bu kaynağın sayfa numaraları esas alınarak yapılmaktadır.), Şöyle Böyle,(Metin aktarma ve Sözlük), Sefa TOPRAK, Kırklareli Üniversitesi, Fen-Edebiyat Fakültesi, Türk Dili ve Edebiyatı Bölümü, Mezuniyet Tezi, Kırklareli, 2013. Danışman: Doç. Dr. Secaattin Tural.

Adres
RumeliDE Dil ve Edebiyat Araştırmaları Dergisi Osmanağa Mahallesi, Mürver Ciçeği Sokak, No:14/8 Kadıköy - ISTANBUL / TÜRKIYE 34714 e-posta: editor@rumelide.com tel: +90 $5057958124,+902167730616$
Address

RumeliDE Journal of Language and Literature Studies

Osmană̆a Mahallesi, Mürver Çiçeği Sokak, No:14/8

Kadıköy - ISTANBUL / TURKEY 34714

e-mail: editor@rumelide.com,

phone: +90 505 7958124, +90 2167730616 
belirten ve bu güzellik algısının da değişkenliğini göz önünde bulunduran Şeyh Vasfi’nin ve Muallim Naci'nin edebiyatta katı bir değişmezlik ve ne olursa olsun var olanın devam ettirilmesi konusunda herhangi bir taassup içinde olmadığı açıktır. Hatta bu ifadeler yeniliğe ve değişime açık olduklarının da bir göstergesidir fakat bu yenilenmenin ölçütü yine "güzel" olana bağlllıktır.

Yaptıkları işin birkaç mektup yazmış olmaktan ibaret olarak algılanacağını düşünseler de amaçlarının, sözün makbul olabilmesi için "hale, zamana, mevkie göre" söylenmiş olması gerektiğini göstermek olduğu bir kez daha dile getirildikten sonra "Mukaddime" bölümü tamamlanır.

İlk mektup Şeyh Vasfînin kaleminden, "Huzûr-ı Mes'ûd-ı Harâbâtîye" hitabıyla başlamaktadır ki Şeyh'e ait bütün mektupların hitabı da bu şekildedir ve Muallim Naci bu mektuplara "Şeyhim" hitabı ile mukabele etmektedir.

\section{Mektupların Muhtevası}

4.a. Birinci Mektuplaşma: Şeyh Vasfî tarafından başlatılan mektuplaşma serüveninin birinci mektubunda Şeyh'in mektubu, arkadaşı Muallim Naci'ye karşı derin bir muhabbet, dostane bir sevgi ve övgü sözleri ile başlar. Burada Şeyh’in, Naci'ye duyduğu büyük muhabbetin ve hürmetin ifadesi olan sözler görülür. Şeyh, Naci'nin hür fikirleri ile parlak zihinleri hayrette bırakmakta bir mahir olduğunu ve edebiyat âlemini adeta nurlandırdığını söyler. Kendisinin de onun yüksek eserlerinden istifade etmekten büyük bir bahtiyarlık duyduğunu belirtir. Ayrıca eserlerini Tercümân-ı Hakîkat'e göndermesine de bu "bahtiyarlık" duygusunun cesaret verdiği şeklinde bir giriş yapar.

Diğer mektupların muhtelif yerlerinde de sıkça rastlayacağımız bu tür muhabbet ifadeleri sunan Şeyh Vasfi, birinci mektubunun devamında içinde bulunduğu bir edebî sohbet ortamından söz açar. Bu mecliste cereyan eden edebiyat ve şiir tartışması birinci mektuplaşmanın da genel çerçevesini oluşturur. Mektupta isimler ... şeklinde gizli tutulmuş olsa da eski ve yeni edebiyat taraftarlarının bir araya geldiği bu mecliste söz, Emir Hüseynî’nin Zâdul Mûsafirîn’inden okunan beyitlerle başlar. Bunun üzerine ismi verilmeyen fakat belli ki eski taraftarı bir Efendi "Önceki ediplerin, edebiyata etmiş oldukları hizmeti içinde bulunduğumuz hamiyet-i milliye gereğince takdir etmemek gibi bir haksızlıkta bulunmazsınız."(s.11) der. Yine ismi verilmeyen fakat sözün muhatabı olarak yeni edebiyat kanadını temsil ettiği anlaşılan bir Efendi de söze karışarak "Şüphe yok. Yalnız bendeniz değil yeni tarz taraftarlarını tamamı dahi takdir eder fakat bununla birlikte öncekilerin sözünü birer açlk ayet olarak da telakki edemezler." şeklinde karşllık verir. Ve "Şark eserlerinin Âşık Garib manzumesinden ibaret olduğunu düşünerek hafife almaya çalışan bazı şık beylere kıyas ederek yeni tarz taraftarlarım kadirşinassızhkla suçlamamanızı rica ederim.” (s.11) der.

Sohbetin devamında tartışmanın itidal üzerinde devam ettiği anlaşılır ve o zamanın modası olan eskiyeni karşıtlığı bahsi bu mecliste de en önemli mevzuu olarak konuşulmaya devam eder. Tartışmada ortak fikir "Âli bir söz söyleyenin küçük bir adam olmaslyla değerinden bir şey kaybetmez. Âli olmayan bir söz de sahibinin büyüklüğ̈̈ ile yücelik kazanmaz." (s.11) kaidesi üzerinde olur ve basit bir sözün sırf sahibinin büyüklüğünden dolayı basitliğinden kurtulamayacağı üzerinde durulur. Bu kaideyi desteklemek üzerine de karşılıklı olarak muhtelif eski şairlerin şiirlerinden örnekler sunulur. Sunulan şiirlerin, hayale, hikmete, âşıklığa ve mana güzelliğine uygunluğu üzerine tartışılır.

Sözün burasında Şeyh Vasfíden de bazı beyitleri çözümlemesi istenir. İşte burada mektubun asıl yazılış gayesi ortaya çıkar ki o da herkesin kendi fikrini kabul ettirmek derdinde olmasıyla sonuçsuz

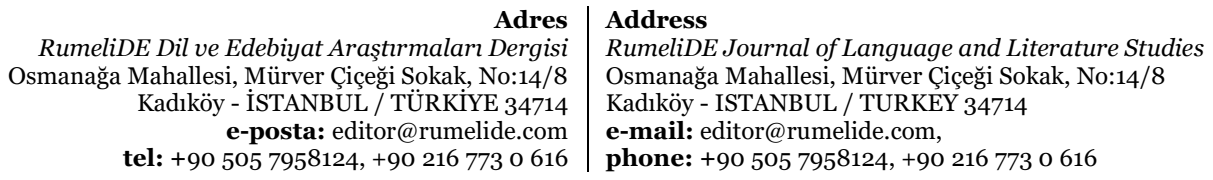


kalan bahiste sözü ve zekâsı güçlü bir zata müracaat etme fikri teklif edilir. Bunun üzerine Şeyh Vasfí, beyitlerin çözümlenmesinde Muallim Naci'den görüşünü ve mana bakımından hangi beytin daha parlak olduğunun tespitini ister.

Muallim Naci'nin cevap olarak yazdığı birinci mektubun girişi de Şeyh Vasfî̀ninkinden çok farklı olmaz. O da Şeyh'in kendisine göstermiş olduğu teveccühe ve muhabbete karşılık olarak: "Fikirleri irşat eden eserlerinizin yeni bir numunesi olan bilgi dolu mektubunuzu okuyarak fikirlerimi bir kat daha kuvvetlendirmiş olduğum cihetle, kemâlinizden istifâde edenlerden addolunacağımı düşündükçe iftihâr ediyorum."(s.16) şeklinde mukabelede bulunur. Mektubun bu giriş bahsi uzunca devam eder ve burada Naci, Şeyhin kendisine olan teveccühünün devamını arzu edişini yazar, bunun gerekçesini de başından geçen bir hâdise ile aktarır. Mektubun bu kısmı samimi bir arkadaş muhabbeti şeklinde cereyan eder.

Sonrasında Şeyh'in sorusunun cevabına geçen Naci, bahsi geçen edebiyat meclisinde olsaydı zikredilen şiirlere karşılık olarak kendisinin de hangi şairin hangi şiirini okuyacağına dair açıklama yaparak ayrıntılara girer ve Hâfız'dan, Mevlana'dan ve Örfî-i Şîrâzî’den beyitler aktarır ve kendisine sorulan beyitler üzerine düşüncelerini aktarır.

O da "Âli bir söz söyleyenin küçük bir adam olmasıyla değerinden bir şey kaybetmez. Âli olmayan bir söz de sahibinin büyüklüğü ile yücelik kazanmaz." ibaresini tasdik ettiğini söyler ve herkesin söyleyeninden önce "sözde mana, manada hakikat, letafet" aradığını ekler. Burada aslından onu eskiyeni edebiyat tartışmaları içerisinde net bir konuma oturtacak kanaatlerini beyan eder:

\begin{abstract}
"Eserler güzel olsun da ister şarka ait olsun; ister garba ait olsun, idrak ehlinin makbulüdür. Şark eserlerini ayıklamaya himmet, garba ait eserlerin seçimine de dikkat etmeliyiz. Dışarıdan alacağımız şeylerin ne gibi şeyler olması gerektiğini neden bilmeyelim? Biz bütün cihanı irşada kâfi gelen "hikmet müminin yitik malıdır, onu nerede olsa bulur, alır." dersini şimdi değil, bin bu kadar sene evvel almış bir milletiz. Şarkın eserlerini ayıklamaktan neden çekinelim? Ne zamana kadar bir takım münasebetsiz sözleri "milli edebiyatımız" diye kendi kendimizi aldatırcasına takdir edip duracağı?"(s.22)
\end{abstract}

Sadece bu tespiti bile, Naci’nin tartışmalar içerisinde konuya bakış açısının itidal üzere, "güzel” olanı arayış olduğunu göstermeye yeter. Ne kalıplaşmış bir eski propagandası ne de tek gerçek değerin yenilik olduğunu savunan bir yok saymadır onunki.

Bu konuda sözüne destek olarak Nâilî-i Kadîm’in meşhur "gideriz" redifli gazelinden örnek verir. Bir zamanlar bu tür beyitlerin büyük kabul gördüğünü bu şiirleri tenkit etmek bir tarafa, insanların beğenmediklerini söylemeleri dahi neredeyse vahyi değersiz göstermek gibi addolunduğunu, onun zamanında ise bu tür beyitleri beğenenlerin ayıplandığını söyleyerek zamanın değişimi ile insanların edebî güzellik algıların da değiştiğini vurgular.

Bir de "hayalince maşukunun kim bilir kaç kulaç uzun olan saçlarmdan kement yaparak geçmiş ömrün boynuna atmak, geri çevirmek için var kuvveti pazıya vererek çekmek zahmetini çeken selhverde şairlere actrm. Ama duramam, bir aralık da gülerim.” (s.26) diyerek eski edebiyatımızda sıkça karşımıza çıkan bir şiir anlayışına karşı çıkar fakat burada Naci’nin karşı çıktığı eski edebiyatın tamamı değildir. Yaptığı eleştiri eski şiirin temel yapısına değil aksine şair tavrı bazındadır zira yine kendisi "zelîlâne" şiirleri beğenemediğini, şair denildiği zaman zihninde "uluvviyet" kavramının parladığını söyler ve "rindane" söyleyiş ile pespayeliğin bir birine karıştırılmaması gerektiğini; şairliği değerli kılanın da söyleyişte sözü zillete düşürmeden âşıkaneliği verebilmek olduğunu belirtir.

\begin{tabular}{|c|c|}
\hline & \\
\hline$m L$ & $J c$ \\
\hline No & ̧a Mahallesi, Mürver Çiçeği Sokak, No:14/8 \\
\hline $\begin{array}{r}\text { Kadıköy - İSTANBUL / TÜRKIYE } 34714 \\
\text { e-posta: editor@rumelide.com } \\
\text { tel: +90 } 5057958124,+90216773 \text { o } 616\end{array}$ & $\begin{array}{l}\text { ISTANBUL / TURKEY } 34714 \\
\text { editor@rumelide.com, } \\
+905057958124,+90216773 \text { o } 616\end{array}$ \\
\hline
\end{tabular}


4.b. İkinci Mektuplaşma: Şeyh Vasfi, birinci mektubunda değerlendirmesini istediği şiirlere vermiş olduğu cevaptan ötürü Muallim Naci’ye teşekkür ve iltifatlarla başlar söze. Devamında yine aralarındaki dostane muhabbet ve bu muhabbeti dile getiren şiirler vardır.

Naci, birinci mektubunda Tercümân-ı Hakîkat'te yazmaya başladıktan sonra neşet eden "nev-zuhûr ahbâ"sının birçoğunun eski muhabbetlerini göstermez olduğundan bahseder ve Şeyh'in dostluğunun devamından emin olup olamayacağını sorar. Şeyh Vasfî de bu suale: "Ulviyetin misâl-i müşahhası olan zâtınız gibi bir sâhib-i fazîlete karşı ibrâz-ı uhuvvete kalkışmam hadd-i nâşinâshlk değil midir? Hiçbir değerim yoksa da haddimi bilmekle müftehirim. Dühate karşı ibrâz-ı uhuvvet değil, ilân-ı ubûdiyyet benim için en büyük şereftir."(s.28) şeklinde cevap verir. Bu mektubun ana konusunu bu bahis oluştururken Şeyh Vasfî, önceki mektupta zikredilen bir rubai hakkında Naci'den yeniden bir mütalaa rica ederek mektubunu sonlandırır.

Naci'nin bu mektuba cevabından mektupların belli bir periyodda değil de muhtelif aralıklarla yazıldığı ve tehirli tarihlerle gazetede yayımlandığı anlaşılır. Belli ki bu mektuplar gerçekten iki edebî dostun samimi olarak birbirlerine yazdıkları mektuplardır ve içeriklerinde dönemin tartışmalı konularına dair bahisler olduğu için de gazetede neşredilmektedir. Burada gazetenin yönetiminde Naci'nin bulunuyor olması da önemli bir etkendir. Kitap şeklinde yayımlanması düşüncesi ise hiçbir mektupta geçmemektedir.

Naci'nin mektubu da beklenildiği üzere Şeyh'e duyulan muhabbet bahsiyle açılır ve derinlemesine devam eder. Şeyh’in talep ettiği rubaiye dair ikinci bir mütalaa ise, Naci tarafından önceki söyledikleri ile iktifa edilmesinin ricası ile karşılıksız kalır. Böylelikle de ikinci mektuplaşma tamam olur.

4.c. Üçüncü mektuplaşma: Şeyh Vasfî, bu mektubunda Naci'ye hitap ederken artık farklı bir boyutta bir iltifatla başlar. Onun Osmanlı edebiyatına yapmış olduğu hizmetleri takdir manasında her gün bir makale yazmış olsa bile yine de bu işi hakkıyla yerine getirememiş olacağını söyler.

Eğer mektupların yazılış tarihlerindeki olaylara dikkatlice bakılacak olursa belki de o günlerde yaşanan önemli bir olay sonrasında Naci'yi teselli etmek için yahut da maruz kaldığı hücumlara karşı destek manasında bu mektubun yazıldığı daha net görebilir. Zira Naci'nin Osmanlı edebiyatına olan katkısının göz ardı ediliyor oluşuna Şeyh'in tepkisi: "Bunu cihanda teslim etmeyecek bir kimse tasavvur olunur mu? Olunsa bile onun takdiri, adem-i takdîri müsâvîdir.” (s.34) şeklindedir.

Mektubun devamında, yeni edebiyatın karşısında eskiyi savunduğu söylenen Şeyh Vasfînin, eskinin savunucu olarak gösterilen Naci'yi yenilikçi olarak görerek sen "Müceddidsin" şeklinde hitap etmesi oldukça dikkate değerdir. Bu iltifat oldukça iddialıdır: "Müceddidsin! Sen gülşen-i edebiyyâtta nağme-pîrâ olah andelbeyân sahnede başka bir âvâz-ı dilnişîn işitilmeğe başladı." (s.34) Burada Naci'nin edebiyatımıza getirdiği bir yenilik etkisinden bahseden Şeyh, onun etkisiyle artık birçok şairin şiir algısının değiştiğini ve genel kabul içerisinde de bu yeni tesirin yerleştiğini söyler.

Bu nokta üzerinde biraz durmak yerinde olur. Zira Şeyh Vasfínin, Muallim Naci’ye "müceddid” olarak hitap etmesinin altı kesinlikle boş değildir. Çünkü Naci'de kendilerini yenilikçi olarak gören Tanzimatçların yapmak isteyip de yapamadıkları çok büyük bir yenilik vardır: şiir dilini halk söyleyişiyle bütünleştirmek. Nitekim Şinasi'nin şiir dilinde yapmak istediği inkılap kendisini ancak Naci'de bulabilir. Ne Namık Kemal, ne Hâmid ne de Ekrem dil ve ahenkte bir bütünlük yakalayabilir. Mehmet Kaplan’a göre Naci, Divan şiiri reaksiyonuna dayandığı için eskici/gerici olarak görülür fakat

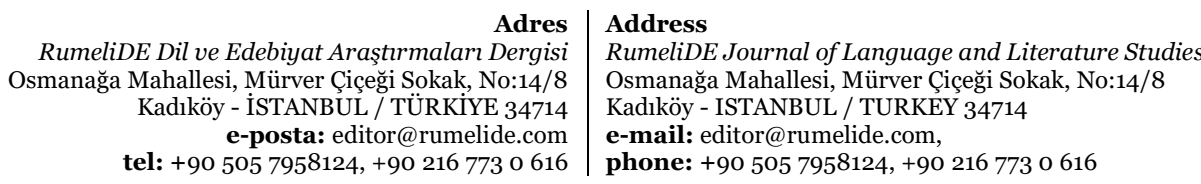


o Divan şiirini asla olduğu gibi alıp devam ettirme derdine düşmez; aksine eski şiirimizin "ifade tarzını" ve "musikisini” alarak konu bütünlüğü içerisinde onu bir kompozisyon haline getirmeyi başarır.(Kaplan, 2010:95)

Naci, Divan şiiri dışında ve geleneğin haricinde bir yenilik yapar. Şiirini baştan sona tek bir kompozisyon şeklinde bir bütünlüğe kavuşturmayı başarır. Onu eski şiirden ve o gelenekten ayıran en önemli özellik budur. Divan şiirinde şiir değil beyit bütünlügü esastır. Bir gazel içerisinden herhangi bir beyti çıkarmak o şiirin manasında bir eksilmeye sebep olmaz, hatta bir gazel yahut kaside içerisinde seçilen bir beyit bütün şiiri gölgesi altında da bırakabilir. Hâlbuki Naci'nin getirdiği yenilikte artık şiirin bir mısraı dahi bütünlüğün ayrılmaz parçası olur ve eksikliği hem manayı hem de söyleyişi etkiler.

Nâci, eski şiirin beyit bütünlüğünü bütün şiirine yaymayı başarır. "Bu bakımdan Naci’nin şïri, diğer Tanzimat şïrlerinden üstündür.”(Kaplan, 2010:96) Bu da onu Şeyh Vasfi'nin tasviri ile "müceddid” yapmaya yetmektedir ki açtığı bu yol kendisinden sonra birçok şairin yürüyeceği ve hatta Mehmet Akif'in, Yahya Kemal'in şiir dilinin oluşmasına öncülük edeceği için edebiyatımızdaki en başarılı yenilik olur. Esasen Tanzimat'ın yenilikçi-öncü şairlerinin yakalamak istediği "yenilik" de aslında budur. Onlar da halk şiirine yakın şiirler yazarak sade, anlaşlır olmaya çalışarak Divan şiirine bir tepki ortaya koyarlar fakat gözden kaçırdıkları nokta söyleyiş ve şairanelik olunca ne halkın zevkine yaklaşabilirler ne de yazdıklarıyla kendilerini memnun edebilirler. Nitekim yeni şiirin en büyük isimleri dahi kendi şiirlerinden değil yine içinde yetiştikleri Divan şiirini okumaktan zevk alırlar. (Bakınız: Tanpınar, 2009) Zira halk şiiri yazmak salt sade bir söyleyişten geçmez. Halk şairlerinin dahi bağlı olduğu bir gelenek, tabi oldukları bir zevk ve söyleyiş anlayışı vardır.

Üçüncü mektubun cevabında Naci, Şeyh Vasfi’ye onu itidal sahibi birisi olarak tanıdığını ne ifrata ne de tefrite meylettiğini fakat kendisine "müceddidsin" şeklinde hitap ederken bu itidal düsturundan uzaklaşmış olduğunu söyler. "Fevkalâde hitâblara mazhar edildiğimi görüyorum da meslek-i muhlisnevâzânede itidâle riâyet buyurmamakta olduğunuzu size ihtâr edeceğim geliyor." (s.45) der ve bu bahis üzerinden daha da fazla durmayarak konuşmayı, Şeyhin mektubundaki diğer bir mesele olarak bahsettiği güfte ile bestelerin uyumu konusuna getirir.

Cevap mektubunun ağırlıklı bölümünü oluşturan bu bahiste Naci "herkes kâbiliyetine göre bir terâne ile mütelezziz olur.” kaidesini kabul etmekle birlikte bizdeki bestelerin güftelerle pek de alakalı olamadığı üzerinde durur. Konu ile alakalı çeşitli örneklemeler yaparak yaşadığı bir anıyı da nakleder.

4.ç. Dördüncü mektuplaşma: Şeyh Vasfî, dördüncü mektubuna Batı edebiyatı ile Klasik edebiyatın mukayese edildiği "sohbetleri dilnişîn, fikirleri metîn" bir edebiyat mahfilinde bulunduğundan bahsederek sözü açar ve mecliste bulunanların Naci'nin birçok beytini ezberden okuduklarını aktarır. Hatta hafızası en zayıf olanın dahi en az yirmi parça ezbere sahip olduğunu söyler.

İşte bu mecliste bulunanlar ile Şeyh Vasfî arasında bir konuşma geçer. Bu konuşma ağırlıklı olarak Muallim Naci ve Şeyh Vasfi’nin yakın dostluğu üzerinedir. Mecliste bulunanların Şeyh'e sordukları sorulardan iki şairin mektuplarının Tercümân-ı Hakîkat'te yayımlanmasının ne kadar büyük bir etki uyandırdığını gösterir. Zira soruların içerikleri tamamen mektuplarda geçen konu ve olaylar üzerinedir. Öyle ki Şeyh’in söylediği bir sözü yahut bir yorumu Naci'nin tasdik etmesine imrenilmekte ve şahsi yorumlar üzerinden onların da Şeyh'e katıldıkları yahut katılmadıkları noktasında fikirlerini

\footnotetext{
\begin{tabular}{r|l} 
Adres & Address \\
RumeliDE Dil ve Edebiyat Araştırmaları Dergisi & RumeliDE Journal of Language and Literature Studies
\end{tabular}

Osmanağa Mahallesi, Mürver Çiçeği Sokak, No:14/8 Osmanağa Mahallesi, Mürver Çiçeği Sokak, No:14/8

Kadıköy - İSTANBUL / TÜRKIYE 34714 Kadıköy - ISTANBUL / TURKEY 34714

e-posta: editor@rumelide.com e-mail: editor@rumelide.com,

tel: +90 505 7958124, +90 2167730616 phone: +90 505 7958124, +90 2167730616
} 
beyan ederler. Naci, mecliste bulunmamakla birlikte sanki oradaymış gibi fikirleri sıkça zikredilip mektuplardaki söyledikleri üzerinden tanık gösterilir.

Konuşmanın sonunda "herkes kâbiliyetine göre bir terâne ile mütelezziz olur" sözünün iki şair tarafından tasdiki noktasında itirazlar ve ihtilaflar çıkar. Bu sözün "fitratta ihtilaf yoktur" kaidesiyle çeliştiğinden bahsederler ve Şeyh'ten açıklama isterler. Şeyh Vasfî de iki asır öncesinde İtalyan müziğinin ortaya çıktığı zaman Almanların, İngilizlerin ve Fransızların o müziği taklit etmek yerine kendi müziklerini ortaya koydukları örneğini vererek "fitratta ihtilâf yoktur ammâ herkes milliyyeti dâiresinde terakkiyi arzu eder" yorumunda bulunur. Fakat iki taraf da bu konuda yeniden Muallim Naci'nin açılayıcı fikrine ihtiyaç duyduğunu söyler ve Şeyh’ten bu konuyu tekraren ona sormasını rica ederler.

Naci, mektubunun başında, Şeyh'in bahsettiği mecliste şiirlerinin ezberden okunuyor olmasına karşı duyduğu memnuniyeti iftiharı ile dile getirir: "Ne kadar müstağni, ne kadar vahşi olursa olsun bir şairin gönlünü avlamanın en kestirme yolu nedir bilir misiniz? Yanında bazı ebyâtını tahsîn-hân olarak okuyuvermek!" ve şairliğin bir gereği olan beğenilmenin ondaki karşllığını dile getirir. "Kendi tabiatımın, âsârımın meftûn-ı mütekebbiri olduğum gibi tahsîn-i halkın dahi âşık-ı mütehassiri idim." (s.59) Sonrasında da kendisine ait birkaç hatırayı nakleder ve tarih düşürme, bir tarihini gazetede yayımlama tecrübesini latife şeklinde anlatır. Devamında bir iki konuya daha temas ettikten sonra sözü yukarıda bahsi geçen konuşmaya getirir ve muhavereyi bir hayli güzel bulur. Kendisinden istenilen görüşü de şu şekilde açılklar:

Naci'ye göre millet olarak taklitten ziyade üretken olunmalıdır. Buradan onun "milliyetçilik" anlayışının izlerini bulmak da mümkündür: şahsi bir teşebbüste dahi milliyetin muhafazası göz önünde bulundurulmalıdır. Bu müzikte de böyledir, sanatta da edebiyatta da. "Bazı efrâd-ı milletimizde görüldüğü üzere "Osmanl müzikası pek nâkıstır diye onu takbîh ile milel-i sâire müzikasına mühimkâne temâyülün mânâsın hiç anlayamam. Müzikamız nâkıs ise onu zemm ile iktifâ edip de ikmâline çalışmamak noksanın daha büyüğü değil midir?”(s.69)

$\mathrm{Bu}$ noktada Naci, millet olarak terakkimizi bir kez ortaya koyabilsek dünyada birinci millet olduğumuzu herkes kabul edecektir düşüncesini taşır. Ona göre eğer bir kişi milli unsurlarına gönülden bağlı değilse ya nankördür yahut kötü bir tiynete sahiptir. Çünkü onun fikrine göre halk tarafından sevilen şeyler "milli şeyler"dir. Örnek olarak da Fransız tiyatrosundan yapılan tercüme bir tiyatro ile bize özgün bir tiyatronun seyirci üzerindeki etkisini gösterir: "Ahalimiz hangisinden memnun ve müteessir oluyor? Elbette bizim yazdığımızdan! Çünkü bizim yazdığımız ahvâl ve ahlâk$\imath$ milliyemize muvâfik bulunuyor. Ammâ Fransız edîbinin eseri bazı rivâyete göre âli şey imiş. Bizimki o kadar değilmiş. Varsin şimdilik olsun. Çalışır isek ileri de bizimki de âli olmayacak mı? Öyle âli olacak ki onun yanında âsâr-ı ecnebiye sâfil görünmeğe başlayacak."(s.70)

Naci, edebiyatımızı Fransız edebiyatına yetiştirmenin mümkün olduğu kanaatindedir. Fakat ona göre, bunun yolu taklitten ve uyarlamalardan ziyade özgün çalışmalardan geçmektedir. Evrensel duyguların var olduğunu elbette bilir ancak halkın hissiyatını bir Fransız duygusuna alıştırmanın mümkün olmayacağını düşünür. Ona göre sair milletlerden yapılacak iktibaslar terakkiye mani olmayacaktır aksine ilerlemeye katkı sağlayacaktır, ancak her millet özellikle de Osmanlı milleti ilerlemeyi kendi içinde aramalıdır ve bu yoldan asla ayrılmamalıdır. Burada Naci, terakkiyi Batı taklidinde gören modernleşme dönemi aydınlarımıza nazaran yerli bir tavır sergilemektedir. Bununla birlikte, gözünü dünyanın gelişmelerine tamamen kapatan bir tavır içinde olmadığı da açıç̧a görülmektedir zira onun

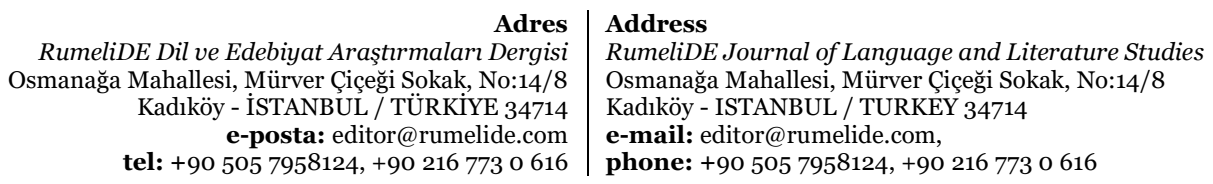


devrinde Türkçe'yi bir şïr dili haline getirmekteki önemli rolü yanında, daima yerli bir çizgi üzerinde ilerleme gayretleri de dikkat çeker. (Okay, 2010: 135)

4.d. Beşinci mektuplaşma: Şeyh Vasfî, canı sıkıldıkça sık sık Ziya Paşa'nın Harâbât'ını okur ve okudukça da zevk alır. Yine bir can sıkıntısı halinde Harâbât okurken yanına bir kişi gelir ve aralarında edebî bir sohbet cereyan eder. Konu Şeyh Vasfînin bir şiirinde geçen "Zelihâ" isminin yazımıyla alakalı imla çelişkisidir. Mevzu uzunca bir bahisle ve örneklemelerle devam eder. Hangi yazımın galat olacağı uzunca tartışılır. Sonrasında konu Şeyh'in Hâtif-i İsfahânî'den iktibas ile Tercümân-ı Hakîkat’te yayınladığı bir "tevhit" tercümesine gelir. İsmi zikredilmeyen şahıs bu tercümeden duyduğu memnuniyeti dile getirir ve kendisinden Şeyh Nizâmî ile İsmet-i Buharî’den de tercüme yapmasını ister.

O kişiye göre böylesine değerli eserlerin tercüme ile kazanılması çok önemlidir zira eskiden milli kütüphanemizde yüksek eserlerin Batıdaki kadar çok olmadığı düşüncesi artık yıkılmıştır bunda da Şeyh Vasfînin oldukça büyük bir gayreti ve emeği vardır. Buradaki emek ve gayretten kasıt Şeyh Vasfi’nin Doğu edebiyatının seçkin isimlerinden yaptığı tercümelerdir. Zira hacimce hiç de azımsanmayacak derecedeki bu çeviriler dönem içerisinde oldukça ilgi uyandırır. Özellikle de genç edebiyatçıların dikkatini çeken bu tercümeler Batıdan yapılan çeviriler karşısında adeta birer mukayese ortamı doğurur. Şeyh Vasfînin bu tercümeleri de onun isminin eskiyi muhafaza ediyor olarak anılmasında etkili olur. Fakat burada esas olan çevirilerin hangi maksat ile yapıldığıdır. Tercümelerin maksadı edebiyat âlemine unutulan isim ve eserleri hatırlatmak, gençlere onları tanıtmakken; yapılan iş eskide takılıp kalmak olarak telakki edilir.

Bu istek üzerine Şeyh Vasfî kendisinde bir "himmet” bulunmadığını asıl yolu açanın Muallim Naci asıl takdir edilecek himmetin ona ait olduğunu söyler. Tercümeleri rica olunan isimlerden Şeyh Nizâmî́nin şiirini kendisi tercüme eder İsmet-i Buharînin gazelini ise "böyle âlî bir eserin tercümesi muktedir bir zâtın kaleminden çıkmalıdır.” diyerek Muallim Naci’ye gönderir.

Naci bu mektuba cevaben, Şeyh'in Harâbât'ı sıkça okumasının şaşılacak bir şey olmadığını bu eserin büyük bir hizmete sahip olduğunu belirtir. Ayrıca böylesine "mümtaz" bir kıymete sahip bir eserin "tahribine kıyâm" edenlerin de dahi kendisinden istifade ettiği halde sirf eseri değersiz göstermek adına "har âbâd" olarak anılmasının büyük bir hamiyetsizlik olduğunu sert bir şekilde ifade eder. Ziya Paşa'nın ise, "Yıkıldı gitti Ziyâ kaldı bir Harâbâtı" gibi sözlerle anılmasını da büyük bir hürmetsizlik olarak görür. Bu konuya sert ve kızgın bir şekilde yaklaşan Nâci'nin edebi esere ve onun sahibine karşı ne kadar hassas bir yaklaşım içinde olduğu görülür.

Sonrasında Naci de "Zelihâ"nın imlası üzerine muhtelif örneklerle fikrini söyler. Sıra tercüme konusuna geldiğinde tercüme türleri olan aynen, mealen, tevsîden bahseder ve bunlar hakkında bilgi verir. Ve tercüme konusunda Şeyh'in kendisinden daha iyi olduğunda israr ederek tercüme etmesini istenilen gazelin yine Şeyh tarafından tercümesinin daha yerinde olacağını söyler. Hatta Nizami'nin dikkate değer başka şiirleri tercüme etmesini de tavsiye eder. Birçok şairden çeşitli tercümeleri bulunan Şeyh Vasfîyi bu konuda israr ile teşvik edenin Muallim Naci olduğunu buradan görmek mümkündür.

4.e. Altıncı mektuplaşma: Kitabın son mektuplaşması olan bu mektubunda Şeyh Vasfî, Naci'ye: "Nev-resîdegân-ı cihân-ı edeb âsâr-ı teâlî-perverâneniz ile tenvîr-i ezhân etmek istiyorlar."(s.103) diyerek onun matbuat âleminde neden uzun bir süredir yer almadığını sorar. Belli ki Muallim Naci

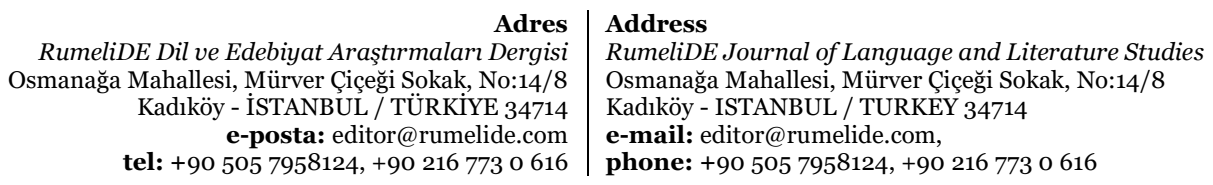


belli bir müddet gazetelerde herhangi bir eser yayımlamamaktadır. Şeyh de bunun sebebini merak eder. Hatime makamında yazılan bu mektupta bahis evvelki mektupta adı anılan tercümelere gelir ve son olarak da tamamlanan bu mektuplaşmanın devam etmesini arzu ettiğini söyler.

Naci de mektuplaşma ve konuşma şeklinde verilen eserlerin daha lezzetli okunduğunu söyler. O da mektuplaşmayı sürdürmek niyetindedir. Çünkü Batı edebiyatında çocukların ve gençlerin eğitimlerinde mektup veya konuşma şeklindeki metinlerin sıklıkla kullanıldığını ve oldukça faydalı olduğunu söyler ve bu konuda çeşitli örnekler verir. Bunun yanında bu tarzın Şark edebiyatında da yer ettiğini söyler ve İmâm-ı Rabbânînin “Mektubatını” örnek olarak gösterir.

Burada Naci’nin bir özelliği daha göze çarpar. O vereceği örneklerde yahut söylemek istediği bir konuda bakışlarını hem geleneğe hem de yeniliğe ortak olarak çevirir. Sadece Batı edebiyatında bulduğu bir örnek ile yetinmez ya da orada bulduğunu tek değer olarak görmeyerek Doğudaki karşılığını da arar ve mukayesesini bu şekilde yapar. İki medeniyeti de takip ediyor ve biliyor olması oldukça önemlidir, adeta faydacılık nazarıyla iki medeniyetin de güzel örneklerini kullanmayı tercih eden Naci, edebiyat olgusuna Doğu-Batı bağlamında bütüncül yaklaşır, hamasi duygulardan da oldukça uzaktır.

Mektuplaşma ile yapmış oldukları hizmetin edebiyata heves eden gençler için faydalı olmasını ümit eder ve bundan sonraki mektuplarında kendilerinin de terakki etmiş olacaklarını söyleyerek mektubuna son verir.

\section{Sonuç}

Şöyle Böyle adlı eser 19. yüzyll edebiyatımızın iki önemli ismi olan Muallim Naci’nin ve Şeyh Vasfìnin karşılıklı olarak edebiyat hakkındaki görüşlerini paylaştıkları mektuplarından oluşur. Şöyle Böyle, gerek edebi mektup türünün güzel bir örneği olması bakımından gerekse edebiyat tarihimiz açısından yaşadıkları dönemde çeşitli edebi tartışmalara konu olmuş iki şairin edebiyat ve şiir hakkındaki görüşlerini barındırıyor olması bakımından oldukça önemli bir eserdir.

Bu çalışmada Şöyle Böyle mektuplarındaki görüşleri ışığında ele alınan Muallim Naci'nin ve Şeyh Vasfînin aslında sadece edebi görüşleri açısından değil birçok olaya bakışları açısından gelişmeyeilerlemeye kapalı bir anlayışa sahip olmadıkları, aksine "sözde mana, manada hakikat, letafet" anlayışları bakımından "güzel" olanı arayış içerisinde oldukları görülür. "Dünyada ne kadar güzel söz var ise cümlesi edebiyattan ma'dûddur, ne kadar çirkin söz var ise cümlesi edebiyattan matrûddur." kaidesinde bulunuyor olmaları bunun bariz örneğidir. Öyle ki bu güzellik arayışında onları Doğu-Batı medeniyeti ayrımında görmek mümkün değildir. Şiirde, musikide ve medeniyet olarak ilerlemede onlar için esas olan taklitten ziyade, milletin menfaatine katkı sağlayacak her şeyin, iyice tetkik edilerek seçilmesi ve iyi olana doğru bir yenilenmenin izlenmesidir. Muallim Naci’nin ve Şeyh Vasfi’nin anlayışında kesinlikle var olanı reddedici bir düstur yoktur sadece edebiyatta, sanatta hatta hemen her alanda iyi ve güzel kıstasıyla seçkinci olmak hassasiyeti vardır ve bir sözün kabul görebilmesi için de mutlaka "hale, zamana, mevkie göre söylenmiş olması gerekmektedir. Onun içindir ki güzel olmayan bir sözü veya tutumu sırf milletimize/geleneğimize aittir diye sahiplenmek gibi derde düşmezler. Edebiyatımızda ve düşünce dünyamızda var olan değerlere de eskimiş veya değersiz gözüyle asla bakmazlar. Batıya dair bakışları ise Batıda var olana bir hayranlık yahut onlara ait her şeyin kabulü şeklinde değildir, bu konuda özellikle de Naci'nin ifadesi ile ne alacağımızı biliyor olmanın ayırımında olmamız gerektiği şeklindedir.

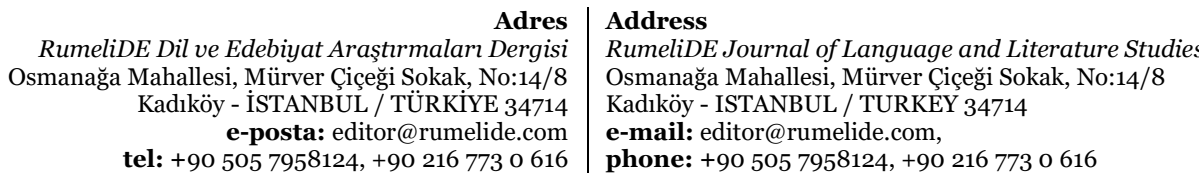


Şöyle Böyle, yaşadıkları dönemde cereyan eden edebiyatta eski-yeni tartışmaları içerisinde eskinin safında gösterilen Muallim Naci ve Şeyh Vasfi’nin aslında, yenilik taraftarı olduğunu iddia eden birçok isimden daha bilinçli bir yenilik fikrine ve hareketine sahip olduğunu göstermektedir. Bu bakımdan mektuplar üzerinde yapılan incelemeler sonucunda iki şairin de içinde yetiştikleri gelenekten bağlarını koparmamakla birlikte, yeniliğe ve modernliğe de kapalı olmadıkları; edebiyata ve sanata Doğu-Batı ayrıştırmasından uzak bir güzellik algısı ile baktıkları sonucuna varılmıştır.

\section{Kaynakça}

Boşça, H.U. (2010). Şeyh Vasfi Hayatı, Sanatı, Eserleri, (Yüksek lisans tezi). Gazi Üniversitesi, Sosyal Bilimler Enstitüsü, Türk Dili ve Edebiyatı Anabilim Dalı, Ankara.

Çetin, N. (2018). Muallim Naci, Tanzimat Edebiyatı içinde (651-701). Ankara: Akçağ.

Enginün, İ. (2012). Yeni Türk Edebiyatı Tanzimat'tan Cumhuriyete. İstanbul: Dergâh.

Gariper, C. (2013). Yeni Türk Edebiyatı El Kitabı. Ankara: Grafiker.

Gökçe, H. (2014). Kefevî Tekkesi Şeyhi Ali Vasfi Efendi Hayatı Sanatı ve Eserleri, (Doktora Tezi). Marmara Üniversitesi, İslam Tarihi ve Sanatları Bilim Dalı, İstanbul.

Kaplan, M. (2010). Şiïr tahlilleri I. İstanbul: Dergâh.

Mes‘ûd-ı Harâbâtî, Şeyh Vasfî. (1302). Şöyle Böyle, İstanbul: Matbaa-i A.K. Tozluyan.

Okay, O. (2010). Batılılaşma Devri Türk Edebiyatı. İstanbul: Dergâh.

Özgül, M. K. (2016). Şïirin Hazanında Gazel Dökenler-V Muallim Naci Efendi. İstanbul: Kitabevi.

Özsarı, M. (2010). Şeyh Vasfî, Türkiye Diyanet Vakfi İslam Ansiklopedisi. (Cilt 39, 71-72. ss.). İstanbul: Türkiye Diyanet Vakf.

Tanpınar, A. H. (2011). Edebiyat Üzerine Makaleler. İstanbul: Dergâh.

Tanpınar, A. H.(2009). XIX. Assr Türk Edebiyatı Tarihi. İstanbul: Yapı Kredi.

[Tansel], F. A. (1953). Muallim Naci İle Recaizâde Ekrem Arasındaki Münakaşalar ve Bu Münakaşaların Sebep Olduğu Edebî Hâdiseler, Türkiyat Mecmuası, 10, 159-200.

Tarakçı, C. (1994). Muallim Nâcî Efendi ve Eserlerinden Seçmeler. Ankara: Kültür Bakanlığı.

Toprak, S. (2013) Şöyle Böyle (Metin Aktarma ve Sözlük), (Yayımlanmamış mezuniyet tezi). Kırklareli Üniversitesi, Fen-Edebiyat Fakültesi, Türk Dili ve Edebiyatı, Danışman: Doç. Dr. Secaattin Tural. Kirklareli.

Uçman, A. (2005). Muallim Nâci. Türkiye Diyanet Vakfi İslam Ansiklopedisi. (Cilt 30, 315-317. ss.). İstanbul: Türkiye Diyanet Vakfi.

Yılmaz, A. (2012). Şeyh Vasfí ve Muallim Naci ile Mektupları: Şöyle Böyle. Uşak: Türkçe Mevsimi.

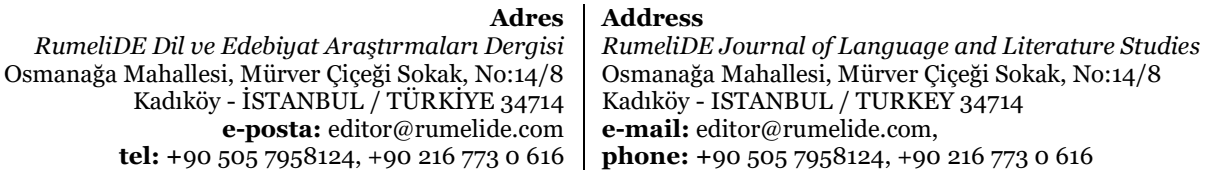

